\title{
An optical method to monitor casein particle size distribution in whey
}

\author{
Hervé Guillemin*, Ioan Cristian Trelea, Daniel PicQue, Bruno Perret, \\ Thomas CATTENOZ, Georges CORRIEU \\ Unité Mixte de Recherche Génie Microbiologique des Procédés Alimentaires, \\ Institut National de la Recherche Agronomique, Centre de Biotechnologies Agro-Industrielles, \\ 78850 Thiverval-Grignon, France
}

Received 6 January 2006 - Accepted 31 August 2006

\begin{abstract}
An optical sensor formerly developed for the monitoring of milk coagulation was modified to allow online determination of casein particle size distribution and of the volume fraction relative to the whey as a function of time. Two methods were assessed to process the signals. The first one was based on the determination of a specific voltage threshold of the optical signal. The results were not satisfying. The second method used multiple thresholds of the optical signal associated with data processing using neural networks. For the considered experimental conditions, the casein particle volume fraction was estimated with a relative error of $23 \%$, and the casein particle size distribution with $7.5 \%$ maximum relative error.
\end{abstract}

casein particle / inline monitoring / infrared sensor / neural network / particle size / curd

摘要 - 光学法检测乳清中酪蛋白颗粒分布。本文采用改进的近红外传感器在线检测凝乳过 程中酪蛋白颗粒大小分布和排除的乳清体积。采用了两种方法处理测定过程的光信号。第 一种方法是基于检测光信号的比國值电压，试验结果不理想。第二种方法是采用光信号多 重阈值电压的方法, 与其对应的大量数据采用神经网络系统进行处理。在现有的试验条件 下，第二种方法测定酪蛋白颗粒与乳清体积比率的相对误差为 $23 \%$, 酪蛋白颗粒大小分布 的最大相对误差为 $7.5 \%$ 。

酪蛋白颗粒 / 在线检测 / 红外线传感器 / 神经网络 / 颗粒大小 / 凝乳

Résumé - Une méthode optique de suivi de la taille de particules de caséine dans le lactosérum. Ce travail propose une nouvelle méthode pour estimer la proportion volumique de grains de caséine par rapport au lactosérum, et la répartition par taille des grains de caséine en fonction du temps. Un capteur optique, mis au point pour suivre en ligne la coagulation du lait, a été adapté. Deux méthodes de traitement des signaux ont été testées. La première, basée sur la détermination d'un seuil spécifique du signal optique, s'avère insuffisante. La seconde fait appel à la détermination de seuils optiques multiples associée à un traitement des données par deux réseaux de neurones. Dans les conditions expérimentales considérées, la proportion de grains de caillé est alors estimée avec une erreur relative de $23 \%$, et la répartition des grains par taille avec une erreur relative maximale de $7,5 \%$

grain de caséine / mesure en ligne / capteur optique infra-rouge / réseau de neurones / taille de particule / caillé

* Corresponding author (通讯作者): guillemi@grignon.inra.fr 


\section{INTRODUCTION}

The syneresis of the curd is one of the most important steps in cheese manufacturing. During this step, the protein network constituting the gel contracts and serum (whey) is expulsed from the curd. The amount of expelled whey and the rate of syneresis create various conditions for the development of microbial strains during ripening and, subsequently, affect the quality of the cheese. Fat and protein lost in the whey, water, minerals and lactate contained in the curd, and $\mathrm{pH}$ of the curd are affected by syneresis. Walstra [20] described the mechanism of gel formation and the possible cause of syneresis as the change in solubility, the rearrangement of the network and the shrinkage of casein particles.

Various variables affect the drainage rate of the curd, such as milk composition (fat, casein concentration and acidity) and rennet or inoculum concentration $[7,9,10$, 13]. Factors associated with the cheesemaking procedure also affect the extent of syneresis. The main variables are the size of the curd particles, the temperature and the pressure applied to the curd. Mechanical stirring is used in some cheese-making technologies to favor coagulum syneresis. For different cheese-making procedures, Whitehead and Harkness [21] showed that the size of the curd cutting had a significant effect on the expulsion of the whey and on the curd moisture content. The larger the curd particles, the higher the final moisture content. Thus, the choice of the particle size is a way of controlling the final cheese moisture.

The cutting and the stirring protocols influence the total amount of whey loss and the final size of curd particles. Johnston et al. [11] suggested that the curd particle size is not only determined by the cutting protocol alone, but also by a combination of the speed and duration of mixing. These results obtained for a type of cheese vat were confirmed by trials carried out in vats with other designs [12]. The authors proposed a model to explain how variation in speed and duration determines curd size particle distribution. Decreasing the curd fine losses and optimizing the moisture level by controlling the curd particle size had a positive effect on both product quality and cheese yield [15]. The draining protocol is generally determined by the cheesemakers and depends on the cheese technology used. Speed of cutting, speed and duration of mixing and temperature are generally fixed and do not change during the process.

Several methods of estimating syneresis, more or less easy to perform, have been described: (a) shrinkage of the curd, (b) amount of whey expulsed from the curd, (c) dry matter of the curd, (d) density of curd and (e) changes in the electrical resistance of the curd. The curd particle size measurement is carried out on a stack of stainless steel mesh sieves from a sample of curd. The curd particles retained on each sieve are weighed, and the result is expressed as the percentage of the total curd [11]. However, this analysis needs time and the result is obtained too late to enable feedback on the process. Online measurement of the curd particle size reduction appears to be a useful approach to control the draining process.

Since the work of McMahon et al. [16] and Banon and Hardy [1], a lot of research has been carried out on the use of optical measurement systems for monitoring coagulum formation in cheese-making $[3,4,8$, $14,17,18]$. An interesting application of optical sensor technology has been proposed by Castillo et al. [5, 6]. Whey fat was considered as an internal tracer of whey expulsion during syneresis. In these studies, the whey fat concentration was predicted by using an optical signal and a power law equation with a coefficient of variation of $6.27 \%$. These authors claimed that the syneresis kinetic rate constant predicted from the optically estimated whey fat concentration values was underestimated. The inaccuracy for the prediction of the syneresis rate constant was attributed to both scatter in actual fat concentration data points, probably associated with whey sampling, and the relatively small decrease in fat concentration during cooking ( 44\%). Moreover, Castillo et al. [7] showed that the mass of whey drained and the kinetic rate constant of syneresis were predicted by an equation that included temperature and 


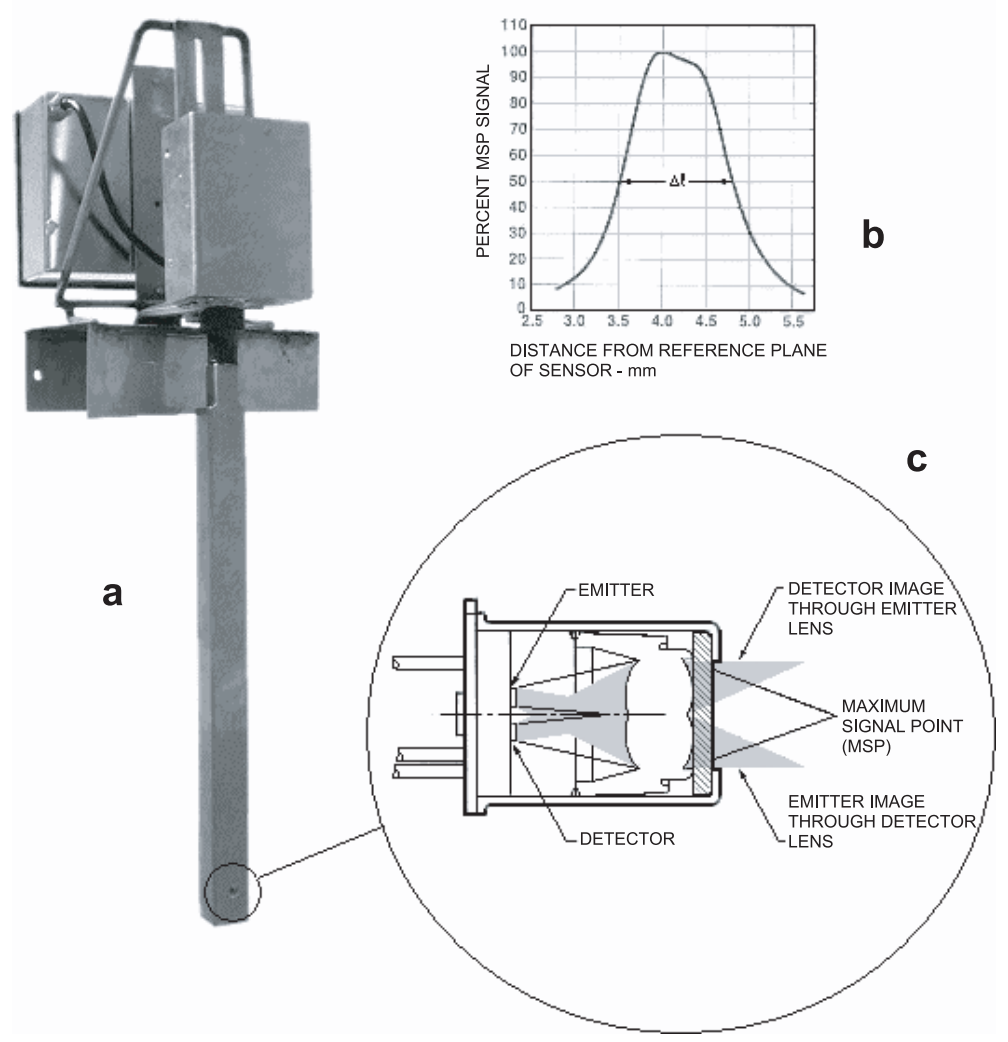

Figure 1. (a) General view of the sensor; (b) LED response in the air. Percentage of reflected signal relatively to the signal level at the Maximum Signal Point (MSP) as a function of distance from reflector; (c) Transmitter-receiver diode cross-section.

coagulation parameters derived from an optical signal. The model predicted the whey drainage with a $\mathrm{R}^{2}$ of 0.96 and a standard error of prediction of $4.43 \mathrm{~g}$ for a variation in whey mass from 0 to $100 \mathrm{~g}$. These authors suggest that it may be possible to develop a sensor capable of monitoring both the coagulation and syneresis processes.

The objectives of this study were to assess the potential of an optical sensor to monitor casein particle size distribution and its volume fraction relative to whey as a function of time. This was a preliminary evaluation of an optical method before its use to monitor curd syneresis in a vat during a real cheese-making process.
The device was realized with a nearinfrared reflectance sensor previously set up for the monitoring of milk coagulation. Two estimation methods were compared in order to calculate the casein particle size distribution and the volume fraction based on the optical signal. They took into account different thresholds of the optical signal and specific data-processing methods.

\section{MATERIALS AND METHODS}

\subsection{Near-infrared optical sensor}

A high-resolution infrared optical sensor [19] was located at the end of a watertight stainless steel pipe (Fig. 1a). The infrared 


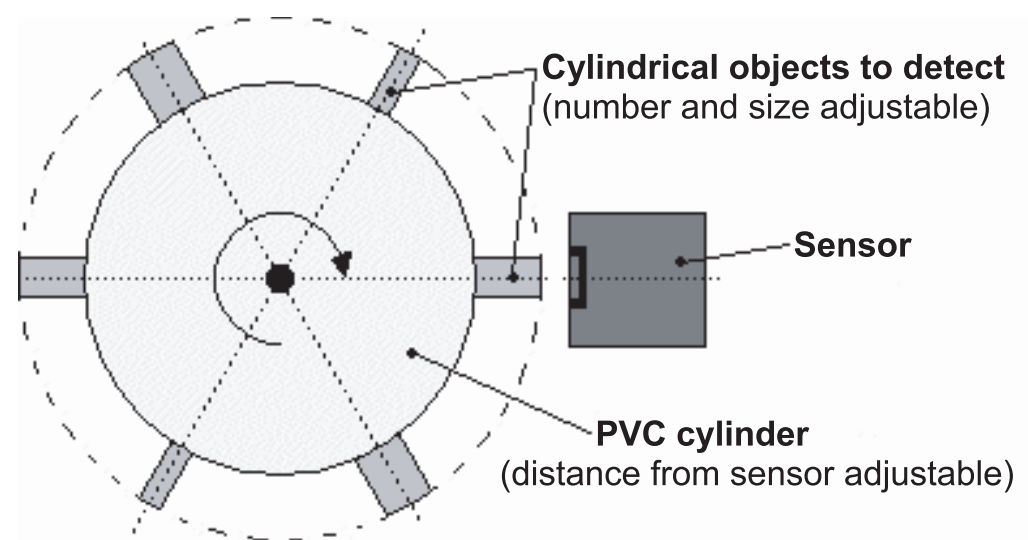

Figure 2. Experimental device used to validate the concept of the optical sensor.

sensor (Fig. 1c) included a built-in optical lens, an emitting $700 \mathrm{~nm}$ wavelength LED, and a photo detector (HBCS-1100, Agilent Technologies). The pipe was immersed in the whey-casein particle mixture.

The sensor provided a low voltage signal depending on its distance from a facing object. The output signal fluctuated each time a particle went through its field of vision. The length of the impulse depended on the particle size, its speed and its direction. The signal amplitude was a non-linear function of the particle-diode distance in the three space directions. Figure $1 \mathrm{~b}$ represents the non-linear response of the diode in the air as a function of the particle-diode distance. The response in whey had the same shape, but its amplitude was significantly reduced (by about $75 \%$ ).

An electronic card including a Digital Signal Processor (DSP) (EZ-Kit Lite for the ADSP-2181, Analog Devices) was used to digitalize and process signals. The choice of this card was motivated by the presence of the embedded DSP, which was well suited to fast signal processing $(48 \mathrm{kHz})$. After the validation of the optical sensor concept, the DSP would make the sensor stand alone (i.e. independent of any PC). The card enclosed a high-pass filter at the input of a 16-bit Digital Analog Converter (DAC). The signal was first filtered, and then digitalized at a frequency of $48 \mathrm{kHz}$. Only the
8 most significant bits were transmitted to a PC computer on a RS232 serial link at 230400 bits per second. The least significant bits were neglected. The signal was processed on the PC in order to benefit from a powerful and user-friendly software environment.

\subsection{Test module}

An experimental device consisting of several PVC cylindrical objects distributed around a central part (Fig. 2) was used to test the optical sensor. The sensor axis and the cylindrical objects were perpendicular to the revolution axis.

Three experiments were realized, based on three different configurations of the test module:

- Configuration 1: The rotational speed of the device was $60 \mathrm{rpm}$. The distance from the revolution axis to the top of the PVC object was $170 \mathrm{~mm}$. The top of the PVC object was $1.4 \mathrm{~mm}$ away from the front of the sensor. The device and the sensor were immersed in water.

- Configuration 2: The same experimental device was used to determine the response of the diode in whey as a function of distance. The PVC objects went through the field of vision of the sensor at different distances from 0 to $3.4 \mathrm{~mm}$ in $0.2-\mathrm{mm}$ steps. 
Table I. Cylindrical object size determination using the optical sensor and the experimental device in Figure 2. Size determined by the single voltage threshold method at different speeds (mean value \pm standard deviation).

\begin{tabular}{|c|c|c|c|c|c|c|}
\hline & & \multicolumn{5}{|c|}{$\begin{array}{l}\text { Rotational speed } \\
\text { (rpm) }\end{array}$} \\
\hline \multicolumn{2}{|c|}{ Objects } & 20 & 39 & 61 & 81 & 100 \\
\hline Number & $\begin{array}{l}\text { Actual size } \\
\quad(\mathrm{mm})\end{array}$ & \multicolumn{5}{|c|}{$\begin{array}{l}\text { Estimated size } \\
\quad(\mathrm{mm})\end{array}$} \\
\hline 3 & 3.1 & $3.4 \pm 0.1$ & $3.4 \pm 0.2$ & $3.3 \pm 0.1$ & $3.4 \pm 0.2$ & $3.3 \pm 0.1$ \\
\hline 3 & 4.1 & $4.5 \pm 0.2$ & $4.4 \pm 0.2$ & $4.1 \pm 0.2$ & $4.2 \pm 0.2$ & $4.2 \pm 0.2$ \\
\hline 5 & 5.5 & $5.6 \pm 0.2$ & $5.7 \pm 0.3$ & $5.3 \pm 0.3$ & $5.4 \pm 0.3$ & $5.4 \pm 0.3$ \\
\hline 5 & 7.1 & $6.9 \pm 0.1$ & $6.9 \pm 0.3$ & $6.9 \pm 0.3$ & $7.0 \pm 0.2$ & $7.0 \pm 0.2$ \\
\hline 3 & 8.1 & $8.1 \pm 0.2$ & $8.2 \pm 0.4$ & $8.1 \pm 0.3$ & $8.2 \pm 0.2$ & $8.2 \pm 0.2$ \\
\hline 2 & 12.9 & $12.8 \pm 0.2$ & $13.0 \pm 0.3$ & $12.7 \pm 0.3$ & $12.8 \pm 0.3$ & $12.8 \pm 0.2$ \\
\hline
\end{tabular}

- Configuration 3: Several cylindrical objects around the central part were used. The number and diameter of the objects are listed in Table I. The device and the sensor were immersed in whey. The rotational speed was constant during an experiment. Five different speeds were used: 20,39, 61, 81 and 100 revolutions per minute (Tab. I). Each trial lasted about 2 min.

\subsection{Calibrated casein particles}

A stock of casein particles (Eurial Poitouraine, Nantes, France) calibrated by size was set up. Particles were made from rehydrated rennet casein powder. A set of sieves was used to define 4 classes of particles: 0.5 to 1,1 to 2,2 to 4 and larger than $4 \mathrm{~mm}$. The casein particle size distribution among classes was selected to simulate the curd particle size evolution during mechanical draining of Emmental (Chamba, personal communication), as follows. Particle sizes usually follow a log-normal distribution. A standard deviation of the logarithm of the diameter equal to 0.5 logarithmic units was found to give adequate spread among classes. The median value of the diameter was varied in order to simulate particle shrinkage: $11.2,5.6,2.8,1.4$ and $0.7 \mathrm{~mm}$. The last four diameter values are the centers (on a logarithmic scale) of the considered four size classes, and the first one was obtained by extension towards large diameters.
The experiments were carried out in a $12-\mathrm{L}$ cheese vat (Guerin, Mauze, France). They consisted of mixing particles of different classes in whey. The volume fraction of particles was determined so that the volume ratio particles/whey was representative for cheese-making: 20, 30 and $40 \%$ (Mietton, personal communication). The re-hydrated casein particle size was checked before and after each experiment, and it was concluded that the size was not significantly different. These stable particles constitute a good material for the calibration of the signal-processing chain.

\subsection{Casein particles/whey volume ratio estimation by the single voltage threshold method}

The first method used to estimate the casein particles/whey volume ratio was based on the use of a single voltage threshold of the pre-processed signal. Suspensions of casein particles belonging to a single size class (either $0.5-1,1-2,2-4$ or $>4 \mathrm{~mm}$ ) were mixed with whey in a $12-\mathrm{L}$ cheese vat (Guerin, Mauze, France). The casein particles/whey volume ratio was 20 , 30 and $40 \%$. Several values of the voltage threshold were chosen from 5 to $10 \mathrm{mV}$. The estimate was defined by the dimensionless ratio (time/time) between the sum of the time intervals when the signal was greater than the voltage threshold and the total measurement time. Several values of 
the voltage threshold were tested from 5 to $10 \mathrm{mV}$. The lower bound of the threshold $(5 \mathrm{mV})$ was chosen high enough to avoid false particle detection due to noise level. The upper bound of the threshold $(10 \mathrm{mV})$ was chosen with respect to the maximum signal response of the sensor in whey (Fig. 4b), in order to detect as many particles as possible.

\subsection{Curd/whey volume ratio and particle size distribution estimation by multiple thresholds and neural networks}

A signal-processing method was proposed that aims to greatly reduce the amount of data contained in the raw signal (from almost 3 million per min to 5) while still retaining relevant information for casein particle size estimation. The processing method included the following steps:

1. The pre-processed DSP signal at $48 \mathrm{kHz}$ was divided into segments of one-minute duration, thus containing $2.88 \times 10^{6}$ measurements. This duration was a compromise between the system reactivity requiring short segments and estimation reliability, which was favored by long time segments.

2. The signal was compared against a set of 10 thresholds (from $2.5 \mathrm{mV}$ to $25 \mathrm{mV}$ in 2.5-mV steps) and the number of times the signal exceeded each of the thresholds in one minute was counted. A set of 10 descriptors for each one-minute signal segment was thus obtained.

3 . The set of 10 descriptors, together with the information about the vat agitation speed, was processed by classical principal component analysis (PCA) in order to further reduce the number of signal descriptors from 11 to 5, while still retaining $99 \%$ of the variance.

4. The resulting 5 signal descriptors were fed into two distinct neural networks. The first one (NN1, characterized by 5 inputs, 6 hidden sigmoid neurons and 1 linear output neuron) estimated the total volume fraction of the casein particles in the whey. The second one (NN2, characterized by 5 inputs, 15 hidden sigmoid neurons and
4 linear output neurons) estimated the size distribution of the casein particles, in terms of the 4 classes mentioned in Section 2.3. For a concise but self-contained description of the neural network modeling methodology, the interested reader is referred for an example to [2].

According to the classical neural network modeling methodology [2], the database was divided into a so-called "learning base" (150 optical signal samples with all condition combinations represented) used for the determination of the PCA and of the neural network and a "validation base" (consisting of the remaining 150 samples) used for independent testing of the signalprocessing chain on previously unseen optical signal samples. The architecture of each neural network (NN 1 and NN 2) providing the best estimation accuracy on the validation database was selected.

\subsection{Assessment of the estimation accuracy}

The accuracy of the estimation of the casein particles/whey volume ratio and of the particle size distribution was assessed by calculating the relative residual error (RRE) as follows:

$$
\begin{aligned}
& R R E=\frac{\sum^{\frac{\sum(\text { Estimated value }- \text { Actual value })^{2}}{\text { Number of measurements }}}}{\text { (Maximum actual value - Minimum actual value })} \\
& \times 100 \% .
\end{aligned}
$$

The relative error has the advantage of being independent of the scale of the variables. For the casein particles/whey volume ratio, the range of the minimum and maximum values were 20 and $40 \%$, respectively. For the particle size distribution this range was between 0 and $100 \%$.

\section{RESULTS AND DISCUSSION}

\subsection{Estimation of the optical signal before DSP electronic card filter}

The high-pass filter included before the DAC on the DSP card may be of capital 

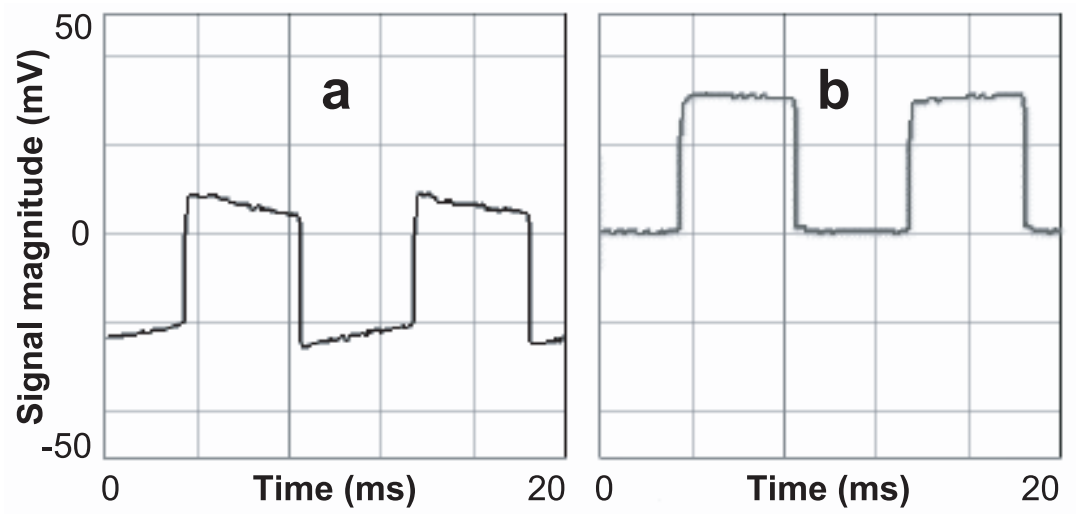

Figure 3. (a) Signal at the output of the DSP card without pre-processing when the input signal was a 30-mV magnitude rectangular signal, with a continuous offset of $15 \mathrm{mV}$, at $100 \mathrm{~Hz}$ frequency and a $50 \%$ cyclical ratio. The signal was deformed by the high-pass filter; (b) The same signal after being pre-processed. The rectangular shape is recovered.

importance with some kinds of signals, such as audio signals. However, in our case it was a drawback since it caused distortion of the optical signal. Thus, the first step in signal processing consisted of estimating the output diode signal, before it was filtered. The estimation method is presented in Appendix A. Figure 3 represents an example of a filtered signal (3a) and processed one ( $3 b)$ corresponding to a synthetic squared input signal with the following characteristics: $30 \mathrm{mV}$ magnitude, $15 \mathrm{mV}$ offset and $100 \mathrm{~Hz}$ frequency.

\subsection{Preliminary validation of the optical measurement device in water and in whey}

Configuration 1 of the test module described in Section 2.2 was used to validate the repeatability of the sensor's response. An example of the pre-processed signal corresponding to a $10 \mathrm{~mm}$ object size is presented in Figure 4a. Its magnitude was compared with a voltage threshold varying in the range 0 to $30 \mathrm{mV}$. At each revolution, the width of the object was simply deduced from the time when the signal level was higher than this voltage threshold. The signal duration was approximately constant whatever the voltage threshold. A $30-\mathrm{mV}$
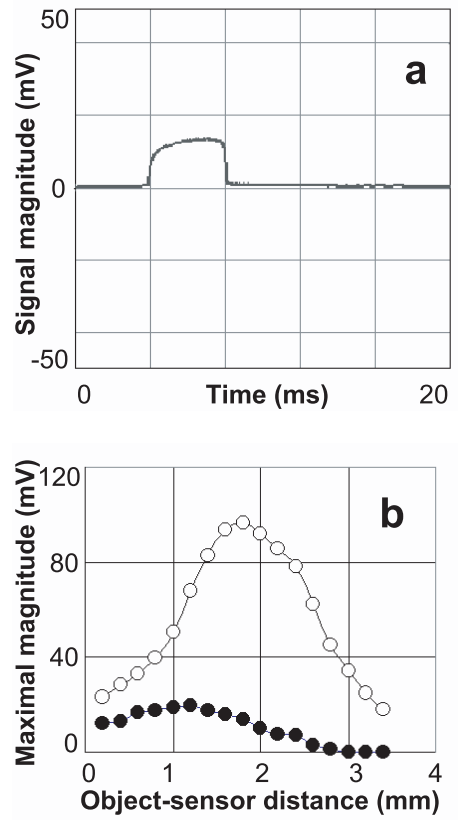

Figure 4. (a) Example of the pre-processed signal corresponding to the $1-\mathrm{cm}$ PVC cylinder passing through the field of vision of the sensor in water; (b) Sensor response as a function of the distance of the object to detect in water (o) and whey $(\bullet)$. 


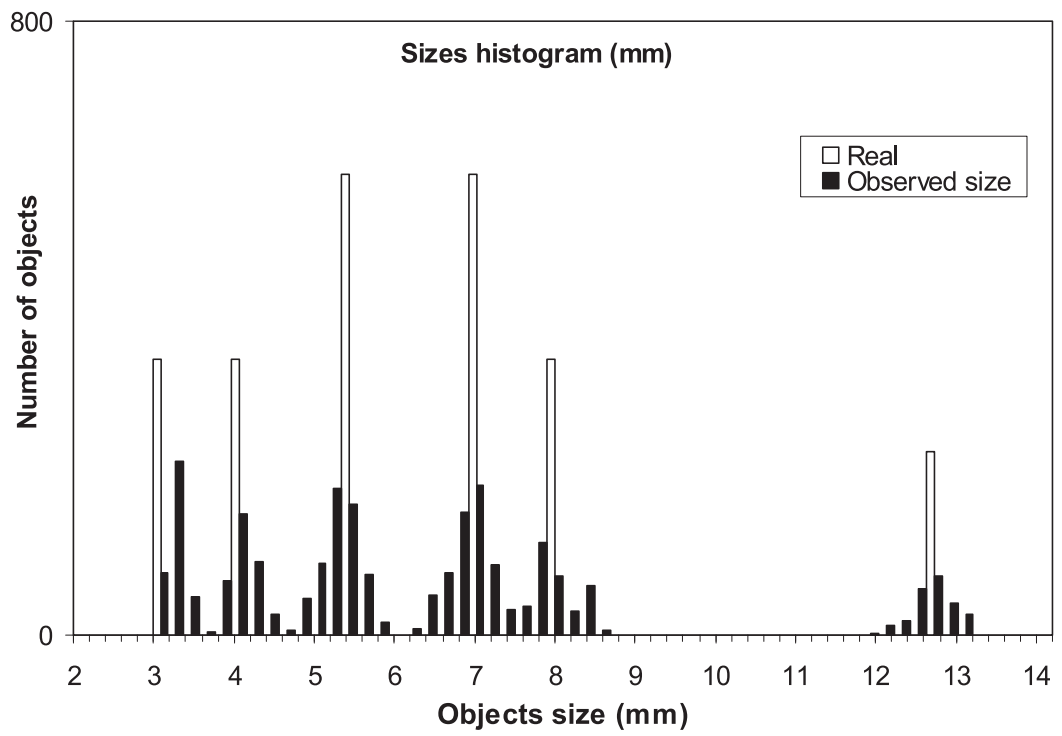

Figure 5. Histogram of measured (black) and real object (white) size when using experimental device in Figure 2. Object number and sizes are listed in Table I. The results were obtained by a simple threshold $(10 \mathrm{mV})$ on the signal. The rotational speed of the PVC cylinder was $61 \mathrm{rpm}$.

threshold was selected. After 54 revolutions, the mean measured size was $9.8 \mathrm{~mm}$ and the standard deviation $0.2 \mathrm{~mm}$.

Configuration 2 of the test module was used to determine the response of the diode in whey versus object-sensor distance. As whey is more opaque to the light emitted by the LED than water, the threshold value was reduced from $10 \mathrm{mV}$ to $5 \mathrm{mV}$. Each time the signal was beyond the voltage threshold, its maximal magnitude was recorded. The obtained values are represented in Figure 4b. The response of the diode in water obtained in the same conditions is also shown for comparison. In water, a maximal magnitude of $95 \mathrm{mV}$ was obtained at $1.8 \mathrm{~mm}$. In whey, the optimal distance from object to sensor was reduced from $1.8 \mathrm{~mm}$ to $1.2 \mathrm{~mm}$; the magnitude was attenuated by a factor of 4. The limit of distance of visibility fell from more than $3.4 \mathrm{~mm}$ in water to $2.6 \mathrm{~mm}$ in whey.

Finally, a mixture of different sized objects at different speeds was studied using configuration 3 of the test module. The histograms of the measured sizes were recorded for different rotational speeds and compared with the theoretical ones. The mean values and the standard deviation for each object size at every speed are given in Table I. For each object size, Fisher's Least Significant Difference test (LSD) results showed that the rotational speeds have no significant effect on the estimated size $(P<0.05)$.

Figure 5 represents the number of objects measured at different sizes for a rotational speed of $61 \mathrm{rpm}$, which corresponds to a linear speed of $53 \mathrm{~cm} / \mathrm{s}$ in front of the sensor. Six distinct classes in the measured sizes centered on the real object sizes were observed. Analogous results were obtained with the other tested speeds. The error in the mean values was $0.4 \mathrm{~mm}$ at worst (object size $=4.1 \mathrm{~mm}$; speed $=$ $20 \mathrm{rpm}$ ), and lower than $0.1 \mathrm{~mm}$ most of the time (Tab. I). The device could distinguish between objects whose size differed by more than one millimeter. 
Table II. Estimated casein particles/whey ratio with a simple voltage threshold method. The particle size classes that best fit reality are emphasized (bold characters) for each of the three voltage threshold values.

\begin{tabular}{lccccccccc}
\hline & \multicolumn{3}{c}{$5-\mathrm{mV}$ threshold } & \multicolumn{3}{c}{$8-\mathrm{mV}$ threshold } & \multicolumn{3}{c}{ 10-mV threshold } \\
\cline { 2 - 11 } & \multicolumn{9}{c}{$\begin{array}{c}\text { Real ratio } \\
(\%)\end{array}$} \\
\hline $\begin{array}{l}\text { Particle size } \\
(\mathrm{mm})\end{array}$ & 20 & 30 & 40 & 20 & 30 & 40 & 20 & 30 & 40 \\
\cline { 2 - 11 } & \multicolumn{8}{c}{$\begin{array}{c}\text { Estimated ratio } \\
(\%)\end{array}$} \\
\hline $0.5-1$ & 61 & 54 & 46 & 36 & 29 & 23 & 13 & 9 & 6 \\
$1-2$ & 75 & 75 & 72 & 62 & 60 & 54 & 45 & 41 & 31 \\
$2-4$ & 41 & 54 & 63 & 27 & 44 & 46 & $\mathbf{2 1}$ & $\mathbf{2 9}$ & $\mathbf{3 0}$ \\
$>4$ & $\mathbf{2 2}$ & $\mathbf{4 0}$ & $\mathbf{5 1}$ & $\mathbf{1 7}$ & $\mathbf{2 7}$ & $\mathbf{3 4}$ & 12 & 19 & 23 \\
\hline
\end{tabular}

Table III. Experimental design with mixtures of different classes of casein particles.

\begin{tabular}{lccccc}
\hline \multicolumn{5}{c}{$\begin{array}{c}\text { Size class } \\
(\mathrm{mm})\end{array}$} \\
& $0.5-1$ & $1-2$ & $2-4$ & $>4$ & \\
\hline $\begin{array}{l}\text { Median particle size } \\
(\mathrm{mm})^{*}\end{array}$ & \multicolumn{7}{c}{$\begin{array}{c}\text { Total percentage } \\
(\%)\end{array}$} \\
\hline 11.2 & 0 & 0 & 2 & 98 & 100 \\
5.6 & 0 & 2 & 24 & 74 & 100 \\
2.8 & 2 & 23 & 52 & 23 & 100 \\
1.4 & 23 & 51 & 22 & 2 & 98 \\
0.7 & 51 & 22 & 2 & 0 & 75 \\
\hline
\end{tabular}

* For a theoretical log-normal size distribution including the $<0.5$-mm particles.

\subsection{Casein particles/whey volume ratio estimation by the single voltage threshold method}

The evolution of the estimated ratio as a function of the particle size was increasing from $0.5-1$ to $1-2 \mathrm{~mm}$ classes, and then slowly decreasing for the classes of higher size, regardless of the threshold used (Tab. II). The best results were obtained for an $8-\mathrm{mV}$ threshold. However, no single voltage threshold value tested was suitable for all the classes and all the ratios. The low accuracy of the estimation could be due to the variation in the object-sensor distance from one object to another. This observation led us to develop a more sophisticated method which takes into account results for different values of the voltage threshold.

\subsection{Casein particles/whey volume ratio and particle size distribution estimation by multiple voltage thresholds and neural networks}

The tests were performed on a database of 300 one-minute optical signal samples obtained in various combinations of casein particle volume fractions and particle size distributions, presented in Table III. Five repetitions of each combination were done. The casein particle size distributions were selected to simulate curd particle size evolution during mechanical draining, as described in Section 2.3. Since particles smaller than $0.5 \mathrm{~mm}$ were not considered, the total percentage of all classes was not 
Table IV. Estimation accuracy of the signal-processing method based on the neural networks. NN 1 was used to model the casein particles/whey ratio, NN2 was used to model the 4 classes of casein particle size (see Materials and Methods).

\begin{tabular}{|c|c|c|}
\hline \multirow[b]{2}{*}{ Estimated parameter } & \multicolumn{2}{|c|}{$\begin{array}{l}\text { Relative residual error } \\
(\%)\end{array}$} \\
\hline & $\begin{array}{l}\text { Learning database } \\
\text { (150 samples) }\end{array}$ & $\begin{array}{c}\text { Validation database } \\
\text { (150 samples) }\end{array}$ \\
\hline Casein particles/whey volume ratio (NN 1) & 21 & 23 \\
\hline Casein particles size distribution (NN 2) & & \\
\hline $0.5-1 \mathrm{~mm}$ & 1.1 & 3.2 \\
\hline $1-2 \mathrm{~mm}$ & 1.6 & 3.0 \\
\hline $2-4 \mathrm{~mm}$ & 2.8 & 5.2 \\
\hline$>4 \mathrm{~mm}$ & 3.0 & 7.5 \\
\hline
\end{tabular}

always equal to $100 \%$. To limit the disintegration and the disappearance of the casein particles as much as possible, the experiments all went on for only five minutes. The re-hydrated casein particle size was checked after the experiments. No significant change was observed.

The obtained estimation accuracies are given in Table IV. The estimation of the casein particles/whey ratio (NN 1) appears to be the most difficult, with a relative residual error of $23 \%$. The estimation of particle size fraction (NN 2) is comparatively more accurate, with a relative residual error comprising between 3 and $7.5 \%$. The fraction of the small particles (less than $2 \mathrm{~mm}$ ) is estimated more accurately than that of the larger particles (more than $2 \mathrm{~mm}$ ). This is compatible with the potential use of the system for the determination of the end of the mechanical draining process, when the particle size reaches the size desired by the cheese-maker. The estimation accuracies for the learning database, used for the development of the signal-processing chain, and for the validation database, not used for sensor calibration, differ by a factor of at most 2.5 . This indicates satisfactory generalization ability to new optical signal samples obtained in similar experimental conditions, and hence potential for use in the cheese-making industry after a calibration phase.

The overall estimation performance can be visually appreciated in Figure 6, where only the 150 optical measurements used from the validation database are shown. Various measurements correspond to various combinations of casein particles/whey volume ratios and particle size distributions (Tab. III). Either two or three replicate measurements for each combination are present in the validation database. The conclusions drawn from Table IV are confirmed. The estimation of the casein particles/whey volume ratio (Fig. 6a) is less accurate than of the size distribution (Fig. 6b). The estimation of the casein particles/whey volume ratio appears to be most difficult when the percentage of large particles (classes 2-4 $\mathrm{mm}$ and $>4 \mathrm{~mm}$ ) is high. Similarly, the percentage of small particles $(0.5-1$ and $1-2 \mathrm{~mm})$ is estimated more accurately than that of the large particles (2-4 and $>4 \mathrm{~mm})$. The exact reason for this phenomenon could not be determined, but it may be related to the geometry of the infrared diode field of vision. The proximity of small particles is expected to cause well separated signal peaks, while peaks caused by large particles are more likely to overlap. The overall accuracy of the casein particle parameter estimation was satisfactory, however.

\section{CONCLUSION}

A new tool to monitor the casein particle size in whey is described. An optical sensor set up for coagulation monitoring was used. Its ability to give measurements correlated 
a

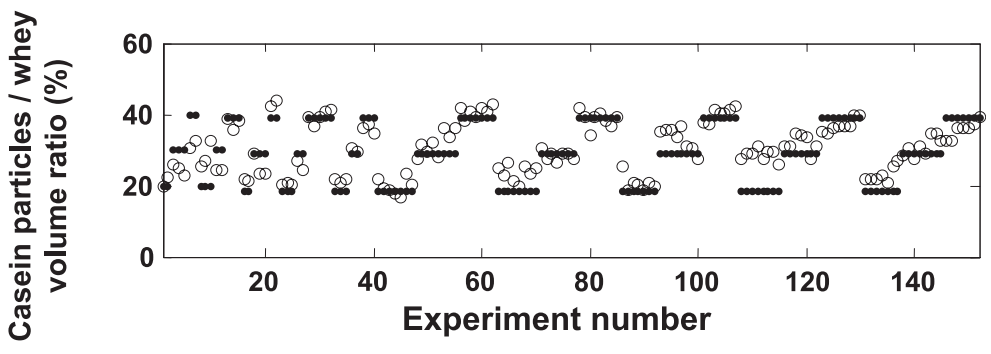

b

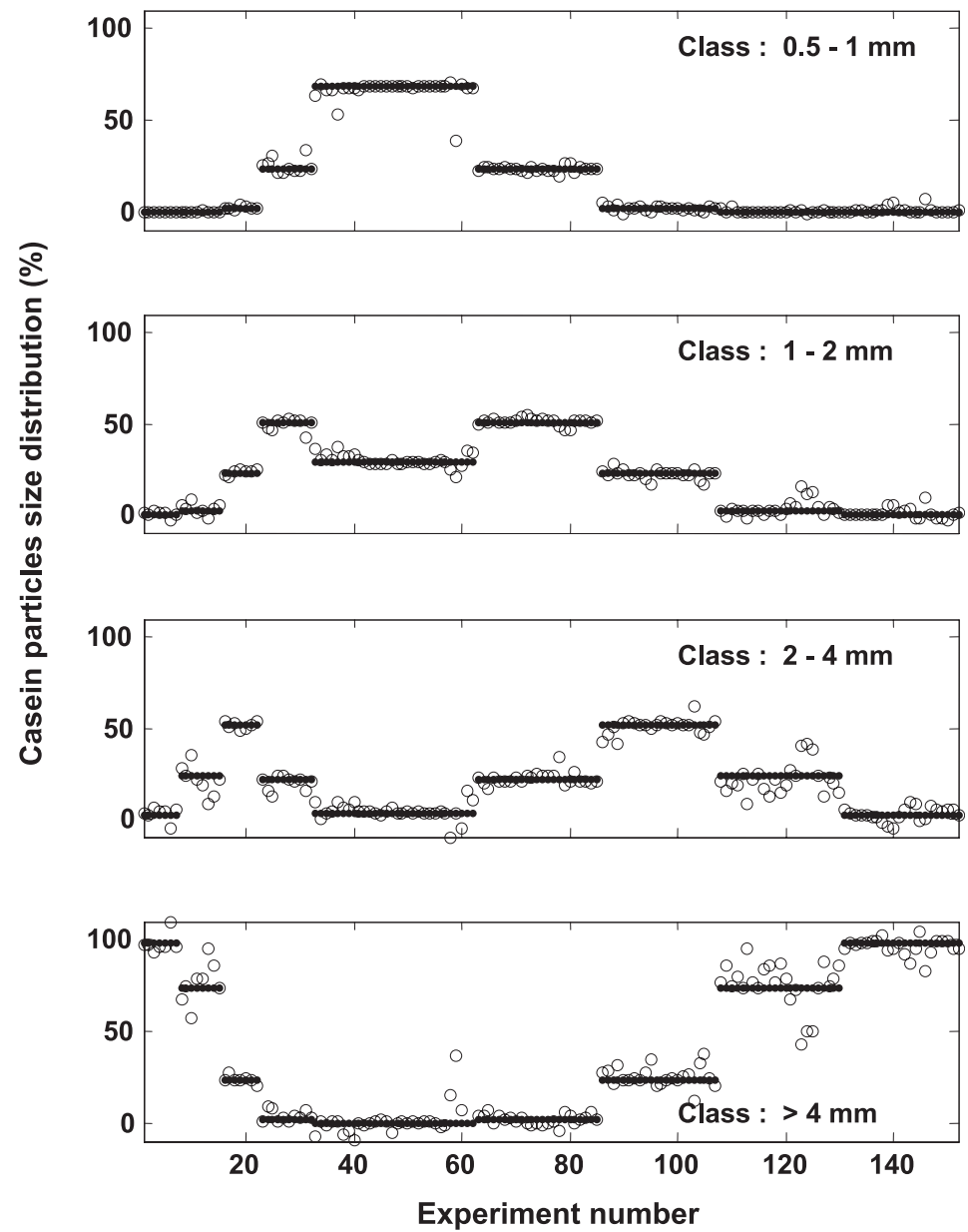

Figure 6. Estimation of the casein particles/whey volume ratio (a) and of the casein particle size distribution (b) using the optical signal-processing method based on neural networks. Application to 150 optical measurements not used for neural network calibration. Real $(\bullet)$ and estimated $(0)$ values. 
to the casein particles/whey volume ratio and the casein particle size distribution was demonstrated. The casein particles/whey ratio and the fraction of casein particles in four different size classes were estimated using two neural networks. The method was validated on mixtures of casein particles of various sizes in whey, obtaining at most $23 \%$ relative estimation error for the casein particles/whey volume ratio and $7.5 \%$ error for the particle size distribution.

These results suggest that this device could be a useful tool for the monitoring of industrial-scale cheese-making processes. It should be borne in mind, however, that these results were obtained in well-controlled laboratory conditions. Transposition to industrial cheese-making conditions would be a non-trivial step. For example, the sensor location inside the vat and the stability of the flow pattern of the whey-curd mixture in front of the optical sensor are expected to be of crucial importance.

However, the experimental results were acquired with casein particles and not with real curd particles in a vat during the cheese-making process. The properties of the real particles might be not the same, as their shape and composition differ, and the composition of the curd particles changes during the process. The heterogeneity of dry matter in curd particles, the outer layer having a much greater dry matter content than the center, would lead to variation in the difference in density between particle and whey. These modifications would change the behavior of particles (speed, orientation, etc.) and increase the uncertainty of the optical measurement. Moreover, variation in the turbidity of the whey can affect the signal. The curd-whey mixture is often diluted with water, which could change the level of the optical signal. Consequently, significant additional trials in real conditions would be necessary to measure the evolution of the curd particles during the process, and a new calibration of the signalprocessing chain will be required to take into account the modifications and to check the ability of this software sensor to monitor the mechanical draining process adequately.
Acknowledgements: This work was sponsored in part by Arilait Recherche (Paris, France). The authors thank C. Vermenot and P. Quemener for their excellent technical assistance.

\section{APPENDIX A}

The first step in signal processing consisted of estimating the output diode signal, before it was distorted by the high-pass filter on the DSP card. It was assumed that the filter was of order one, with its time constant $\tau$. The equation between the output diode signal $\mathrm{v}_{1}$ and the filtered signal $\mathrm{v}_{2}$ was:

$$
\begin{gathered}
\tau \frac{\mathrm{dv}_{2}}{\mathrm{dt}}+\mathrm{v}_{2}=\frac{\mathrm{dv}_{1}}{\mathrm{dt}} \\
\text { or } \mathrm{v}_{1}(t)=\tau \mathrm{v}_{2}(t)+\int_{0}^{\mathrm{t}} \mathrm{v}_{2}(x) \mathrm{d} x+\mathrm{c}
\end{gathered}
$$

where $\mathrm{c}$ was a constant.

In practice, to compute $\mathrm{v}_{1}$, we only had a numerical series corresponding to approximate values of the $v_{2}$ signal at time $\mathrm{k} \Delta \mathrm{t}$, where $\Delta \mathrm{t}$ is the data acquisition period on the PC. We noted $\mathrm{v}_{2}[n]$ the $n$th sample of the series. The $n$th sample $\mathrm{v}_{1}[n]$ was estimated by:

$$
v_{1}[n]=b_{1}[n]-m_{1}[n]
$$

with

$$
\begin{gathered}
b_{1}[n]=\tau v_{2}[n]+\sum_{k=0}^{n}\left(v_{2}[k]-\overline{\mathrm{v}_{2}}[k]\right) \\
\mathrm{m}_{1}[n]=\frac{1}{2 N+1} \sum_{k=-N}^{N} \mathrm{~s}_{1}[n-k] \\
\mathrm{s}_{1}[n]=\operatorname{Min}\left\{\mathrm{b}_{1}[n-k], N \leq k \leq N\right\} \\
\overline{\mathrm{v}_{2}}[n]=\frac{1}{2 N+1} \sum_{k=-N}^{N} \mathrm{v}_{2}[n-k] .
\end{gathered}
$$

$\left(b_{1}\right)$ was a numerical approximation of relation (2). To avoid numerical divergence, we subtracted from each sample $\left(v_{2}\right)$ its 
mean value $\left(\overline{\mathrm{v}_{2}}\right)$ during $1 \mathrm{sec}$. This time was determined by $N$. The final estimate of $\left(\mathrm{v}_{1}\right)$ series was obtained by subtracting $\left(b_{1}\right)$ and $\left(\mathrm{m}_{1}\right)$, which represented low variations of $\left(b_{1}\right)$ series minima. The resulting signal had a constant sign. Its residual variations were reduced. A median filter on 21 points was then applied to reduce electronic noise.

The ignorance of constant $c$, the lack of calculation accuracy and numerical stability problems led us to approximate a solution by relation (3). However, this solution was only satisfying after some period necessary for the particles to become more mobile. At the beginning of the mechanical draining step, the mixture casein particles-whey was compact, and most of the casein particles were almost motionless; namely, in front of the sensor.

The estimation was validated on synthetic signals produced by a wave generator. The generator was plugged into the input of the DSP card. The signal was rectangular, of $30 \mathrm{mV}$ magnitude and with a $15 \mathrm{mV}$ constant offset. As expected, whatever the value of the constant offset, the observed filtered and processed signals were left unchanged.

In order to simulate objects of different size passing through the sensor's field of view at the same speed, we did trials with a constant frequency of $100 \mathrm{~Hz}$ and three different cyclic ratios: $20 \%, 50 \%$ and $80 \%$. Then we did trials with a constant $50 \%$ cyclic ratio and three frequencies $(1 \mathrm{~Hz}$, $10 \mathrm{~Hz}$ and $1 \mathrm{kHz}$ ) to simulate objects of the same size passing through the sensor's field of view at three different speeds. Each trial was conducted for $1 \mathrm{~min}$. The calculation was made afterwards. The value of the constant time $\tau$ was determined so that the shape of resulting signals was rectangular on the largest possible frequency domain. The results were satisfying for all trials. Figure 3 represents an example of a filtered signal (left) and a processed one (right) with a $50 \%$ cyclic ratio and $100 \mathrm{~Hz}$ frequency.

\section{REFERENCES}

[1] Banon S., Hardy J., Study of acid milk coagulation by an optical method using light reflection, J. Dairy Res. 58 (1991) 75-84.
[2] Bishop C.M., Neural networks and their applications, Rev. Sci. Instrum. 65 (1994) 1803-1832.

[3] Castillo M., Payne F.A., Hick C.L., Lopez M.B., Predicting cutting time and clotting time of coagulation goat's milk using diffuse reflectance: effect of $\mathrm{pH}$, temperature and enzyme concentration, Int. Dairy J. 10 (2000) 551-562.

[4] Castillo M., Payne F.A., Hick C.L., Laencina J.S., Lopez M.B., Modelling casein aggregation and curd firming in goat's milk from backscatter of infrared light, J. Dairy Res. 70 (2003) 335-348.

[5] Castillo M., Payne F.A., Lopez M.B., Ferrandini E., Laencina J.S., Optical sensor technology for measuring whey fat concentration in cheese making, J. Food Eng. 71 (2005) 354360.

[6] Castillo M., Payne F.A., Lopez M.B., Ferrandini E., Laencina J.S., Preliminary evaluation of an optical method for modeling the dilution of fat globules in whey during syneresis of cheese curd, Appl. Eng. Agric. 21 (2005) 265-269.

[7] Castillo M., Lucey J.A., Wang T., Payne F.A., Effect of temperature and inoculum concentration on gel microstructure, permeability and syneresis kinetics. Cottage cheese-type gels, Int. Dairy J. 16 (2006) 153162.

[8] Castillo M., Payne F.A., Wang T., Lucey J.A., Effect of temperature and inoculum concentration on prediction of both gelation time and cutting time: Cottage cheese-type gels, Int. Dairy J. 16 (2006) 147-152.

[9] Daviau C., Pierre A., Famelart M.H., Goudédranche H., Jacob D., Garnier M., Maubois J.L., Residual amount of water in a draining curd of Camembert cheese and physicochemical characteristics of the drained curd as modified by the $\mathrm{pH}$ at renneting, the casein concentration and the ionic strength of milk, Lait 80 (2000) 555-571.

[10] Daviau C., Pierre A., Famelart M.H., Goudédranche H., Jacob D., Garnier M., Maubois J.L., Whey drainage during soft cheese manufacture and properties of drained curd as modified by casein concentration, whey protein to casein ratio, and pasteurisation of milk, Lait 80 (2000) 573-587.

[11] Johnston K.A., Dunlop F.P., Lawson M.F., Effects of speed and duration of cutting in mechanized cheddar cheese making on curd particle size and yield, J. Dairy Res. 58 (1991) 345-354.

[12] Johnston K.A., Luckman M.S., Lilley H.G., Smale B.M., Effect of various cutting and 
stirring conditions on curd particle size and losses of fat to the whey during Cheddar cheese manufacture in Ost vats, Int. Dairy J. 8 (1998) 281-288.

[13] Kaytanli M., Erdem Y.K., Tamer I.M., Factors affecting whey drainage rate of renneted skim milk gels: A kinetic approach, Milchwissenschaft 49 (1994) 197-200.

[14] Laporte M.F., Martel R., Paquin P., The near infrared probe for monitoring rennet coagulation in cow's milk, Int. Dairy J. 8 (1998) 659-666.

[15] Lucey J., Kelly J., Cheese yield, J. Soc. Dairy Technol. 47 (1994) 1-14.

[16] McMahon D.J., Brown R.J., Ernstrom C.A., Enzymatic coagulation of milk casein micelles, J. Dairy Sci. 67 (1984) 745-748.

[17] Mertens B.J.A., O’Donnell C.P., O'Callaghan D.J., Modelling near-infrared signals for on- line monitoring in cheese manufacture, J. Chemometr. 16 (2002) 89-98.

[18] Payne F.A., Hicks C.L., Shen P.S., Predicting of optimal cutting time of coagulation milk using diffuse reflectance, J. Dairy Sci. 52 (1993) 48-61.

[19] Perret B., Picque D., Cattenoz T., Corrieu G., Procédé de contrôle de l'égouttage des grains de caillé et dispositif pour sa mise en œuvre, French Patent $n^{\circ}$ FR2822953, 2002.

[20] Walstra P., The syneresis of curd, in: Fox P.F. (Ed.), Cheese: Chemistry, Physics and Microbiology, Volume 1: General Aspects, 2nd edn, Chapman \& Hall, London, UK, 1993, pp. 141-191.

[21] Whitehead H.R., Harkness L., The influence of variations in cheese-making procedure on the expulsion of moisture from cheddar cheese curd, Aust. J. Dairy Technol. 9 (1954) 103-107. 